\title{
Physiological changes and growth of soursop plants under irrigation with saline water and $\mathrm{H}_{2} \mathrm{O}_{2}$ in post-grafting phase
}

\section{Alterações fisiológicas e crescimento de gravioleira cultivadas com águas salinas e $\mathrm{H}_{2} \mathrm{O}_{2}$ na fase pós-enxertia}

\author{
Luana Lucas de Sá Almeida Veloso ${ }^{1 *}$; Geovani Soares de Lima ${ }^{2}$; Carlos Alberto \\ Vieira de Azevedo ${ }^{2}$; Reginaldo Gomes Nobre ${ }^{3}$; André Alisson Rodrigues da Silva ${ }^{1}$; \\ Jessica Dayanne Capitulinoㅜㄹ Hans Raj Gheyi²; Benedito Ferreira Bonifácio ${ }^{1}$
}

\section{Highlights:}

Hydrogen peroxide mitigated the effect of salt stress on photosynthetic pigments.

Salinity damaged the physiology of grafted soursop plants.

Cell damage was reduced with application of hydrogen peroxide.

\begin{abstract}
The low availability of water associated with high salt concentrations in irrigation water has become one of the leading challenges for agricultural production in the semiarid region of Northeastern Brazil. Thus, the study of strategies to enable the use of saline water in agriculture is essential. From this perspective, this study aimed to evaluate alterations in gas exchange, chloroplast pigments, and cell damage in soursop (Anonna muricata L.) irrigated with saline water and under exogenous application of hydrogen peroxide $\left(\mathrm{H}_{2} \mathrm{O}_{2}\right)$ in the post-grafting phase. A study was conducted in Campina Grande, $\mathrm{PB}$, under greenhouse conditions. The treatments were distributed in a randomized block design, in a 4 $\times 2$ factorial arrangement, consisting of four levels of electrical conductivity of water (ECw; 1.6; 2.4; 3.2 and $\left.4.0 \mathrm{dS} \mathrm{m}^{-1}\right)$ and two concentrations of $\mathrm{H}_{2} \mathrm{O}_{2}(0$ and $20 \mu \mathrm{M})$ with four replications. Irrigation water salinity from $1.6 \mathrm{dS} \mathrm{m}^{-1}$ caused changes in the stomatal conductance, respiration, and internal $\mathrm{CO}_{2}$ concentration of soursop plants. A $20 \mu \mathrm{M}$ concentration of $\mathrm{H}_{2} \mathrm{O}_{2}$ reduced the effects of salinity on transpiration and $\mathrm{CO}_{2}$ assimilation values, in addition to promoting the biosynthesis of photosynthetic pigments and reducing cell damage in soursop plants, at 150 days after transplantation. The exogenous application of $20 \mu \mathrm{M} \mathrm{H}_{2} \mathrm{O}_{2}$ reduced the deleterious effects of salinity on the stem diameter of both rootstock and scion in soursop plants irrigated with $\mathrm{ECW}$ of $1.6 \mathrm{dS} \mathrm{m}^{-1}$. The exogenous application of $20 \mu \mathrm{M} \mathrm{H}_{2} \mathrm{O}_{2}$ was not efficient in mitigating the damage caused by salinity on the stem diameter of the soursop at grafting point.
\end{abstract}

Key words: Annona muricata L. Reactive oxygen species. Salinity.

1 Discentes do Curso de Doutorado do Programa de Pós-Graduação em Engenharia Agrícola, Universidade Federal de Campina Grande, UFCG, Centro de Tecnologia e Recursos Naturais, Campina Grande, PB, Brasil. E-mail: luana_lucas_15@hotmail.com; andrealisson_cgpb@hotmail.com; dayanne.jessica@hotmail.com

2 Profs., Programa de Pós-Graduação em Engenharia Agrícola, Centro de Tecnologia e Recursos Naturais, UFCG, Campina Grande, PB, Brasil. E-mail: geovani.soares@pq.cnpq.br; cvieiradeazevedo@gmail.com; hans@pq.cnpq.br

3 Prof., Departamento de Ciências e Tecnologia, Universidade Federal Rural do Semi-Árido, UFERSA, Caraúbas, RN, Brasil. E-mail: rgomesnobre@yahoo.com.br

*Author for correspondence 


\title{
Resumo
}

\begin{abstract}
A baixa disponibilidade da água associada as altas concentrações de sais da água de irrigação, tornou-se um dos principais desafios para produção agrícola no semiárido do Nordeste brasileiro. Dessa forma, o estudo de estratégias para viabilizar o uso da água salina na agricultura é fundamental. Assim, objetivouse com a pesquisa avaliar alterações nas trocas gasosas, pigmentos cloroplastídicos e danos celular em gravioleira (Anonna muricata L.) na fase pós-enxertia irrigada com águas salinas e aplicação exógena de peróxido de hidrogênio $\left(\mathrm{H}_{2} \mathrm{O}_{2}\right)$. A pesquisa foi conduzida em condições de casa de vegetação em Campina Grande-PB. Os tratamentos foram distribuídos no delineamento de blocos casualizados, em esquema fatorial $4 \times 2$, sendo constituídos de quatro níveis de condutividade elétrica da água - CEa $(1,6$; 2,4; 3,2 e 4,0 dS m $\left.{ }^{-1}\right)$ e duas concentrações de $\mathrm{H}_{2} \mathrm{O}_{2}(0$ e $20 \mu \mathrm{M})$, com quatro repetições. A salinidade da água de irrigação a partir de $1,6 \mathrm{dS} \mathrm{m}^{-1}$ causa alterações na condutância estomática, transpiração e concentração interna de $\mathrm{CO}_{2}$ das plantas de gravioleira. A concentração de $20 \mu \mathrm{M}$ de $\mathrm{H}_{2} \mathrm{O}_{2}$ mitigou os efeitos da salinidade sobre a transpiração e taxa de assimilação de $\mathrm{CO}_{2}$, além de promover a biossíntese dos pigmentos fotossintéticos e reduzir o dano celular a gravioleira, aos 150 dias após o transplantio. A aplicação exógena de $20 \mu \mathrm{M} \mathrm{de} \mathrm{H}_{2} \mathrm{O}_{2}$ reduz o efeito deletério da salinidade sobre o diâmetro do caule do porta-enxerto e do enxerto das plantas de graviola irrigadas com água de $1,6 \mathrm{dS} \mathrm{m}^{-1}$. A aplicação exógena de $20 \mu \mathrm{M}$ de $\mathrm{H}_{2} \mathrm{O}_{2}$ não é eficiente em mitigar os danos causados pela salinidade sobre o diâmetro do caule no ponto de enxertia de gravioleira.
\end{abstract}

Palavras-chave: Annona muricata L. Espécie reativa de oxigênio. Salinidade.

\section{Introduction}

Belonging to the Annonaceae family, soursop (Anonna muricata L.) is a fruit species native to the warmest tropical areas of South and North America and subtropical parts of the world (Nahida et al., 2020). Economically, this species is highlighted by the high commercial value of its fruits and the use of the plant by the pharmaceutic and cosmetic industries, given its role as a source of therapeutic constituents, rich in tannins, phenolic compounds, flavonoids, and alkaloids, among others. (Byuna, Songab, \& Kima, 2020).

Most commercial soursop orchards in Brazil are located in the Northeast region, more specifically in Bahia state. This region usually presents high temperatures, low rainfall, irregular rainfall distribution, and intense evaporation in most months of the year, making irrigation an indispensable practice to ensure satisfactory agricultural production (Lima et al., 2018). However, the low water availability associated with the high concentrations of salts in the water used for irrigation is one of the leading agricultural challenges in the modern world (Pailles et al., 2020).
The direct effects of high contents of soluble salts on the physiology, growth, and productivity of plants usually include the increase of osmotic stress, which increases water absorption and ion toxicity or the imbalanced accumulation of specific ions, such as $\mathrm{Cl}^{-}$and $\mathrm{Na}^{+}$, among others (Minhas, Ramos, Ben-Gal, \& Pereira, 2020). In this manner, plants subjected to abiotic stress can present photosynthetic inhibition, chloroplast photooxidation, enzyme inactivation, degradation of photosynthetic pigments, and lipidic peroxidation of membranes (Cova et al., 2020).

Considering that most agricultural species are glycophytic, that is, sensitive to high salt concentrations, the use of strategies aiming at mitigating the damage caused by salinity to plants has been studied to increase plant tolerance to stresses, highlighting the use of hydrogen peroxide $\left(\mathrm{H}_{2} \mathrm{O}_{2}\right)$ (A. A. R. da Silva et al., 2019; Liu, Huang, Lin, \& Sun, 2020).

Hydrogen peroxide is a byproduct of anaerobic and photosynthetic metabolism, which act as a significant regulator component for being interrelated with signal transduction in plants. The 
positive role of $\mathrm{H}_{2} \mathrm{O}_{2}$ in plants subjected to several abiotic stresses has led to an understanding that it is not only a free radical generated as a byproduct of oxidative stress but also useful in maintaining cell homeostasis in cultivated plants (Nazir, Fariduddin, \& Khan, 2020).

In small quantities, $\mathrm{H}_{2} \mathrm{O}_{2}$ acts as a key molecule that regulates photosynthesis, stomatal movement, flower development, leaf senescence, and chlorophyll content; whereas, at high levels, it leads to the oxidative explosion of organic molecules, which may lead to cellular death (Černý, Habánová, Berka, Luklová, \& Brzobohatý, 2018). Exogenous application of hydrogen peroxide was efficient for mitigating the negative effects caused by salinity in certain crops, such as rice (Carvalho et al., 2011), maize (Gondim, Miranda, Gomes, \& Prisco, 2013), and soursop (A. A. R. da Silva et al., 2019).

Therefore, identifying the $\mathrm{H}_{2} \mathrm{O}_{2}$ concentration that mitigates the negatives effects of water salinity, which afflicts several agricultural areas in the semiarid region (A. A. R. da Silva et al., 2019) is of utter importance for social and economic development. In this context, this study aimed to evaluate the effect of $\mathrm{H}_{2} \mathrm{O}_{2}$ to induce tolerance to salt stress through gas exchanges, chloroplast pigments, and cellular damage in soursop plants under greenhouse conditions in the post-grafting phase.

\section{Material and Methods}

The experiment was conducted using 250-L plastic recipients adapted as drainage lysimeters, in a greenhouse belonging to the Academic Unit of Agricultural Engineering of the Federal University of Campina Grande (UAEA/UFCG), in Campina Grande, PB, Brazil, located at the geographic coordinates $7^{\circ} 15^{\prime} 18^{\prime} \mathrm{S}, 35^{\circ} 52^{\prime} 28^{\prime \prime} \mathrm{W}$, elevation of $550 \mathrm{~m}$ a.s. 1 .

The experimental design was in randomized blocks, in a 4 x 2 factorial arrangement, corresponding to four conductivity levels of the irrigation water $(\mathrm{ECw} ; 1.6,2.4,3.2$, and $4.0 \mathrm{dS}$ $\mathrm{m}^{-1}$ ) and two concentrations of hydrogen peroxide $\mathrm{H}_{2} \mathrm{O}_{2}(0$ and $20 \mu \mathrm{M})$ with four replications, totaling 32 plants.

The plant material used in the experiment was soursop 'Morada Nova', which was used for being well-received by producers, forming most commercial orchards in Brazil, besides possessing larger fruits that can weigh up to $15 \mathrm{~kg}$ and higher production compared to the remaining soursop cultivars (Veloso et al., 2018).

The grafted soursop plants used in this study came from the Federal University of Campina Grande and at transplantation, were 90 days postgrafting and were 330 days old. After transplanting, the grafted seedlings underwent an acclimatization period in the greenhouse (30 days), being irrigated with low-salinity water $\left(0.38 \mathrm{dS} \mathrm{m}^{-1}\right)$, after which, application of the treatments began.

The scions used through whip grafting were obtained from an agricultural area belonging to the municipality of Lagoa Seca, PB, being removed from plants of the soursop cultivar Morada Nova that had already fructified.

Lysimeters used for the conduction of the experiment were filled with a $1-\mathrm{kg}$ layer of fine gravel, followed by $250-\mathrm{kg}$ of Regolithic Neosol (Psammitic) with a sandy-loam texture. Two drains were connected to the base of each lysimeter, using a plastic tube with a 4-mm diameter to direct the drained water into a plastic bottle. The base of each lysimeter was wrapped with a non-woven geotextile (Bidim OP 30) to avoid obstruction by soil.

The soil was collected at $0-30 \mathrm{~cm}$ layer depth, in the municipality of Lagoa Seca, PB, which was ground, sieved, and later analyzed for soil characterization regarding the chemical and physical attributes (Table 1), according to the methodologies proposed by Teixeira, Donagemma, Fontana and Teixeira (2017). 
Irrigation waters with different electrical conductivities were prepared by dissolving the salts $\mathrm{NaCl}, \mathrm{CaCl}_{2} \cdot 2 \mathrm{H}_{2} \mathrm{O}$, and $\mathrm{MgCl}_{2} \cdot 6 \mathrm{H}_{2} \mathrm{O}$, at the equivalent ratio of $7: 2: 1$, respectively, in the local supply water $\left(\mathrm{ECW}=0.38 \mathrm{dS} \mathrm{m}^{-1}\right)$. This ratio is commonly found in water sources used for irrigation in small properties of the Northeast region (Medeiros, 1992), based on the relationship between the $\mathrm{ECW}$ and the concentration of salts $\left(\mathrm{mmol}_{\mathrm{c}} \mathrm{L}^{-1}=\right.$ $10 \mathrm{ECw} \mathrm{dS} \mathrm{m}{ }^{-1}$ ) recommended by Richards (1954).

Table 1

Chemical and physical characteristics of the soil used in the experiment, before applying the treatments

\begin{tabular}{|c|c|c|c|c|c|c|c|c|c|}
\hline \multicolumn{10}{|c|}{ Chemical characteristics } \\
\hline \multirow{2}{*}{$\begin{array}{c}\mathrm{pH}\left(\mathrm{H}_{2} \mathrm{O}\right) \\
(1: 2.5)\end{array}$} & \multirow{2}{*}{$\begin{array}{c}\mathrm{OM} \\
\%\end{array}$} & \multirow{2}{*}{$\begin{array}{c}\mathrm{P} \\
\left(\mathrm{mg} \mathrm{kg}^{-1}\right)\end{array}$} & $\mathrm{K}^{+}$ & $\mathrm{Na}^{+}$ & $\mathrm{Ca}^{2+}$ & $\mathrm{Mg}^{2+}$ & $\mathrm{Al}^{3+}+\mathrm{H}^{+}$ & \multirow{2}{*}{$\begin{array}{l}\text { ESP } \\
(\%)\end{array}$} & \multirow{2}{*}{$\begin{array}{c}\mathrm{EC}_{\mathrm{se}} \\
\left(\mathrm{dS} \mathrm{m}^{-1}\right)\end{array}$} \\
\hline & & & \multicolumn{5}{|c|}{ 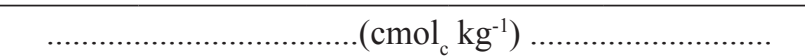 } & & \\
\hline 5.90 & 1.36 & 6.80 & 0.22 & 0.16 & 2.60 & 3.66 & 1.93 & 1.87 & 1.0 \\
\hline \multicolumn{10}{|c|}{ Physical characteristics } \\
\hline \multicolumn{3}{|c|}{ Size fraction $\left(\mathrm{g} \mathrm{kg}^{-1}\right)$} & Textural & \multicolumn{2}{|c|}{ Water content $(\mathrm{kPa})$} & \multirow{2}{*}{ AW } & \multirow{2}{*}{$\begin{array}{c}\text { Total } \\
\text { porosity \% }\end{array}$} & $\mathrm{BD}$ & $\mathrm{PD}$ \\
\hline Sand & Silt & Clay & class & $\begin{array}{r}33.42 \\
\ldots \ldots \ldots \ldots \ldots . .\end{array}$ & $\begin{array}{c}1519.5 \\
{\text { dag } \mathrm{kg}^{-1}}\end{array}$ & & & \multicolumn{2}{|c|}{$\left(\mathrm{kg} \mathrm{dm}^{-3}\right)$} \\
\hline 732.9 & 142.1 & 125.0 & SF & 1.98 & 4.32 & 7.66 & 47.74 & 1.39 & 2.66 \\
\hline
\end{tabular}

OM - Organic matter: Walkley-Black Wet Digestion; $\mathrm{Ca}^{2+}$ and $\mathrm{Mg}^{2+}$ extracted with $1 \mathrm{M} \mathrm{KCl} \mathrm{pH} \mathrm{7.0;} \mathrm{Na}^{+}$and $\mathrm{K}^{+}$extracted with 1 $\mathrm{M} \mathrm{NH}_{4} \mathrm{OAc} \mathrm{pH} 7.0 ; \mathrm{H}^{+}$and $\mathrm{Al}^{3+}$ extracted with $0.5 \mathrm{M} \mathrm{CaOAc} \mathrm{pH} 7.0$; ESP - Exchangeable sodium percentage; ECse- electrical conductivity of the saturation extract; SF- Sandy loam; AW - Available water; BD- Bulk density; PD- Particle density.

Irrigation with saline waters began at 30 days after transplanting of the seedlings to the lysimeters and performed every three days by applying a sufficient water depth to maintain soil moisture close to field capacity, with the amount to be applied being determined according to the water demand of the plants, estimated by the water balance given by the subtraction of the drained volume from the volume applied in the previous irrigation, plus a leaching fraction of 0.15 . The leaching fraction was applied every 15 days.

A $20 \mu \mathrm{M}$ concentration of $\mathrm{H}_{2} \mathrm{O}_{2}$ was obtained by diluting with distilled water. Foliar spraying began at 30 days after transplanting (DAT), with applications on the abaxial and adaxial surfaces of the leaves, in 30-day intervals, from 5:00 pm to 5:45 pm, using a backpack sprayer.

Fertilization with $100 \mathrm{mg} \mathrm{kg}^{-1} \mathrm{~N}, 300 \mathrm{mg} \mathrm{kg}^{-}$ ${ }^{1} \mathrm{P}_{2} \mathrm{O}_{5}$, and $150 \mathrm{mg} \mathrm{kg}^{-1} \mathrm{~K}_{2} \mathrm{O}$ potassium was based on the methodology proposed by Novais, Neves and Barros (1991) for in-pot studies, using urea, monoammonium phosphate, and potassium chloride as sources, respectively. Fertilization with NPK was divided into 12 applications, which were performed monthly. To meet the demand for micronutrients, the plants were sprayed biweekly with a nutritive solution containing $2.5 \mathrm{~g} \mathrm{~L}^{-1}$ of a commercial product, which had the following composition: $\mathrm{N}(15 \%), \mathrm{P}_{2} \mathrm{O}_{5}(15 \%), \mathrm{K}_{2} \mathrm{O}(15 \%), \mathrm{Ca}(1 \%), \mathrm{Mg}$ (1.4\%), S (2.7\%), Zn (0.5\%), B (0.05\%), Fe (0.5\%), $\mathrm{Mn}(0.05 \%), \mathrm{Cu}(0.5 \%)$, and Mo (0.02\%), which were applied on the adaxial and abaxial surfaces.

Agricultural practices consisted of manual hoeing, soil surface scarification before each irrigation event, and plant training. Furthermore, insecticides of the neonicotinoid chemical group, fungicides of the triazole chemical group, and acaricides of the abamectin chemical group were applied whenever necessary. 
The following variables were evaluated at 150 DAT: stomatal conductance $\left(g s ; \mathrm{mol} \mathrm{H}_{2} \mathrm{O}\right.$

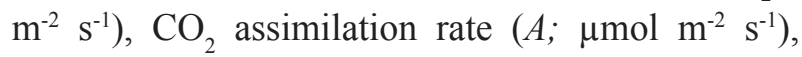

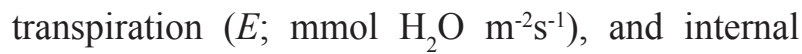

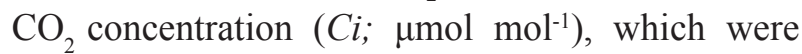
determined between 7:00 a.m. and 8:00 a.m. using a portable infrared gas analyzer (IRGA), model LCPro + Portable Photosynthesis System ${ }^{\circledR}$, produced by ADC BioScientific LLC, London, United Kingdom. These data were used to quantify the intrinsic water use efficiency (WUEi; A/E) $\left[\left(\mu \mathrm{mol} \mathrm{m} \mathrm{m}^{-2} \mathrm{~s}^{-1}\right)(\mathrm{mmol}\right.$ $\left.\left.\mathrm{H}_{2} \mathrm{O} \mathrm{m}^{-2} \mathrm{~s}^{-1}\right)^{-1}\right]$ and the instantaneous carboxylation efficiency $(\mathrm{CEi} ; \mathrm{A} / \mathrm{Ci})\left[\left(\mu \mathrm{mol} \mathrm{m}^{-2} \mathrm{~s}^{-1}\right)\left(\mu \mathrm{mol} \mathrm{mol}^{-1}\right)^{-1}\right]$.

The content of chlorophyll $a, b$, total, and carotenoids were determined at 150 DAT, according to the methodology recommended by Arnon, Emam, Rousta and Ashraf (2017), using five leafblade discs from the third mature leaf from the apex, which were collected, immersed in $80 \%$ acetone, and stored in the dark for 48 hours. The extracts obtained were subjected to readings in a spectrophotometer at wavelengths of 470, 646, and $663 \mathrm{~nm}$. The values observed in the readings were subjected to the following equations: chlorophyll a $(\mathrm{Chl} a)=(12.21$ $\times$ ABS663) - (2.81 × ABS646); chlorophyll $b(C h l$ $b)=(20.13 \times$ ABS64 $)-(5.03 \times$ ABS663 $)$, and carotenoids $($ Car $)=[(1000 \times$ ABS470) $-(1.82 \times$ Chl $a)-(85.02 \times C h l b)] / 198$. The values obtained for the leaf contents of chlorophylls $a, b$, total, and carotenoids were expressed in $\mathrm{mg} \mathrm{g}^{-1} \mathrm{FM}$ (fresh matter).

The percentage of cellular damage $(\% \mathrm{D})$ was also analyzed at 150 DAT. A copper perforator was used to obtain 5 leaf discs of known area per experimental unit, which were washed and put in Erlenmeyer flasks containing $50 \mathrm{~mL}$ of distilled water. After being closed with aluminum foil, the Erlenmeyer flasks were maintained at $25^{\circ} \mathrm{C}$ for 90 min, after which period the initial conductivity of the medium (Xi) was measured using a benchtop conductivity meter (MB11, MS Techonopon ${ }^{\circledR}$ ). Afterward, the Erlenmeyer flasks were subjected to $80^{\circ} \mathrm{C}$ for $90 \mathrm{~min}$ in a forced-air oven (SL100/336,
SOLAB $\left.^{\circledR}\right)$. After cooling, the final conductivity was measured (Xf). The percentage of cell damage was expressed as the conductivity percentage in relation to the total conductivity after the treatment was applied for 90 minutes at $80^{\circ} \mathrm{C}$ : [(Xi/Xf) x 100] (F. D. F. Silva, Rocha, Brito, Sofiatti, \& Beltrão, 2011).

The rootstock diameter $\left(\mathrm{SD}_{\text {rootstock }}\right)$, grafting point diameter $\left(\mathrm{SD}_{\text {grafting point }}\right)$, and scion diameter $\left(\mathrm{SD}_{\text {scion }}\right)$ were measured at 150 DAT to evaluate the growth of soursop plants. The $\mathrm{SD}_{\text {rootstock }}$ was measured at $2.0 \mathrm{~cm}$ from the soil surface; the $\mathrm{SD}_{\text {rootstock }}$ was determined on the spot of the connection between rootstock/scion; and the $\mathrm{SD}_{\text {scion }}$ was determined at $4.0 \mathrm{~cm}$ above the grafting point. A digital pachymeter was used for the measurements.

The data were subjected to analysis of variance by the F-test and when significant, linear regression or quadratic analysis were performed for the water salinity levels. The mean comparison test (Tukey's test at 0.05 ) was used for the concentrations of $\mathrm{H}_{2} \mathrm{O}_{2}$. When a significant interaction between the factors occurred, the salinity factor was later analyzed considering each concentration of $\mathrm{H}_{2} \mathrm{O}_{2}$, using the statistical software SISVAR-ESAL (Ferreira, 2019).

\section{Results and Discussion}

According to Table 2, there was a significant interaction $(p<0.01)$ between the salinity levels and concentration of hydrogen peroxide for the $\mathrm{CO}_{2}$ assimilation rate $(A)$. The salinity levels were significant for stomatal conductance $(g s)$, transpiration $(E), \mathrm{CO}_{2}$ assimilation rate $(A)$, and internal $\mathrm{CO}_{2}$ concentration $(C i)$. The $\mathrm{H}_{2} \mathrm{O}_{2}$ concentrations significantly influenced only $E$ and $A$ of the soursop plants at 150 DAT.

The increment in the salinity of the irrigation water reduced the stomatal conductance of soursop plants. According to the regression equation (Figure $1 \mathrm{~A})$, irrigation with water of the highest salinity level $\left(4.0 \mathrm{dS} \mathrm{m}^{-1}\right)$ reduced $g_{S}$ by $20.19 \%$ compared to plants irrigated with the lowest salinity level (1.6 
$\left.\mathrm{dS} \mathrm{m}^{-1}\right)$. Normally, the first symptom of salt stress is evidenced at the stomatal level, in which the plants respond by closing their stomata as a tolerance measure to salinity, reducing the transpiration of leaves and/or preventing an excessive water deficit in the tissues, allowing recovery of the leaf (Hasan, Sabet, Malakouti, Mokhtassi-Bidgoli, \& Homaee, 2020). Similar results were verified by Santana,
Coelho, Gonçalves and Cruz (2019) for the banana crop grown under different water salinity levels $\left(0.5,2.0,3.0\right.$, and $\left.4.0 \mathrm{dS} \mathrm{m}^{-1}\right)$, in which the authors verified a reduction of stomatal conductance with the increase in ECW applied to the soil, possibly due to the increase in resistance to $\mathrm{CO}_{2}$ diffusion caused by the high salinity levels of the irrigation water in the soil solution.

Table 2

Summary of $\mathrm{F}$ test for stomatal conductance (gs), transpiration $(E), \mathrm{CO}_{2}$ assimilation rate $(A)$, internal $\mathrm{CO}_{2}$ concentration $(\mathrm{Ci})$, instantaneous carboxylation efficiency $(\mathrm{CE} i)$ and intrinsic water use efficiency (WUEi) of soursop plants 'Morada Nova' irrigated with saline waters and subjected to exogenous application of hydrogen peroxide, at 150 days after transplanting

\begin{tabular}{|c|c|c|c|c|c|c|}
\hline \multirow{2}{*}{ Source of variation } & \multicolumn{6}{|c|}{ F Test } \\
\hline & $g s$ & $E$ & $A$ & $\mathrm{Ci}$ & $C E i$ & WUEi \\
\hline Salinity levels (SL) & $* *$ & $* *$ & $* *$ & $* *$ & ns & ns \\
\hline Linear regression & $* *$ & $* *$ & $* *$ & $* *$ & ns & ns \\
\hline Quadratic regression & ns & ns & $*$ & ns & ns & ns \\
\hline Hydrogen peroxide $\left(\mathrm{H}_{2} \mathrm{O}_{2}\right)$ & ns & $* *$ & $* *$ & $\mathrm{~ns}$ & ns & ns \\
\hline Interaction $\left(\mathrm{NS} \times \mathrm{H}_{2} \mathrm{O}_{2}\right)$ & ns & ns & $* *$ & ns & ns & ns \\
\hline Blocks & ns & $\mathrm{ns}$ & ns & ns & ns & ns \\
\hline $\mathrm{CV} \%$ & 10.86 & 16.89 & 10.86 & 12.66 & 36.62 & 18.52 \\
\hline
\end{tabular}

$\mathrm{ns}, *$ and $* *$ respectively, not significant, significant at $p<0.05$ and $p<0.01$.

Leaf transpiration (Figure 1B) of the soursop plants was linearly reduced with the increase in salinity of the irrigation water. The reduction was equivalent to $0.14 \mathrm{mmol} \mathrm{H}_{2} \mathrm{O} \mathrm{m}^{-2} \mathrm{~s}^{-1}$ corresponding to $6.85 \%$ per unit increase of $\mathrm{ECw}$; that is, the leaf transpiration of the soursop leaves was $18.47 \%$ lower in plants irrigated with water at the highest salinity level $\left(4.0 \mathrm{dS} \mathrm{m}^{-1}\right)$ compared to those irrigated with 1.6 $\mathrm{dS} \mathrm{m} \mathrm{m}^{-1}$. There is a directly proportional relationship between stomatal conductance $(g s)$ and transpiration $(E)$ so that the reduction of stomatal conductance contributes to the reduction of transpiration since the stomata are a gateway for gas and water exchange in plants and exert a strong influence on the characteristics associated with photosynthesis and transpiration (Yuping, Hongbin, Yuanyuan, \& Suiqi, 2017). Simões, Coelho, Mesquita, Calgaro and Silva (2020), when evaluating the physiological and biochemical responses of sugarcane varieties to salt stress, observed a reduction in the transpiration rate of plants with the increase in salinity, and highlighted that such a reduction is a strategy of the plant to reduce water loss through transpiration, constituting a resistance mechanism to salt stress. 

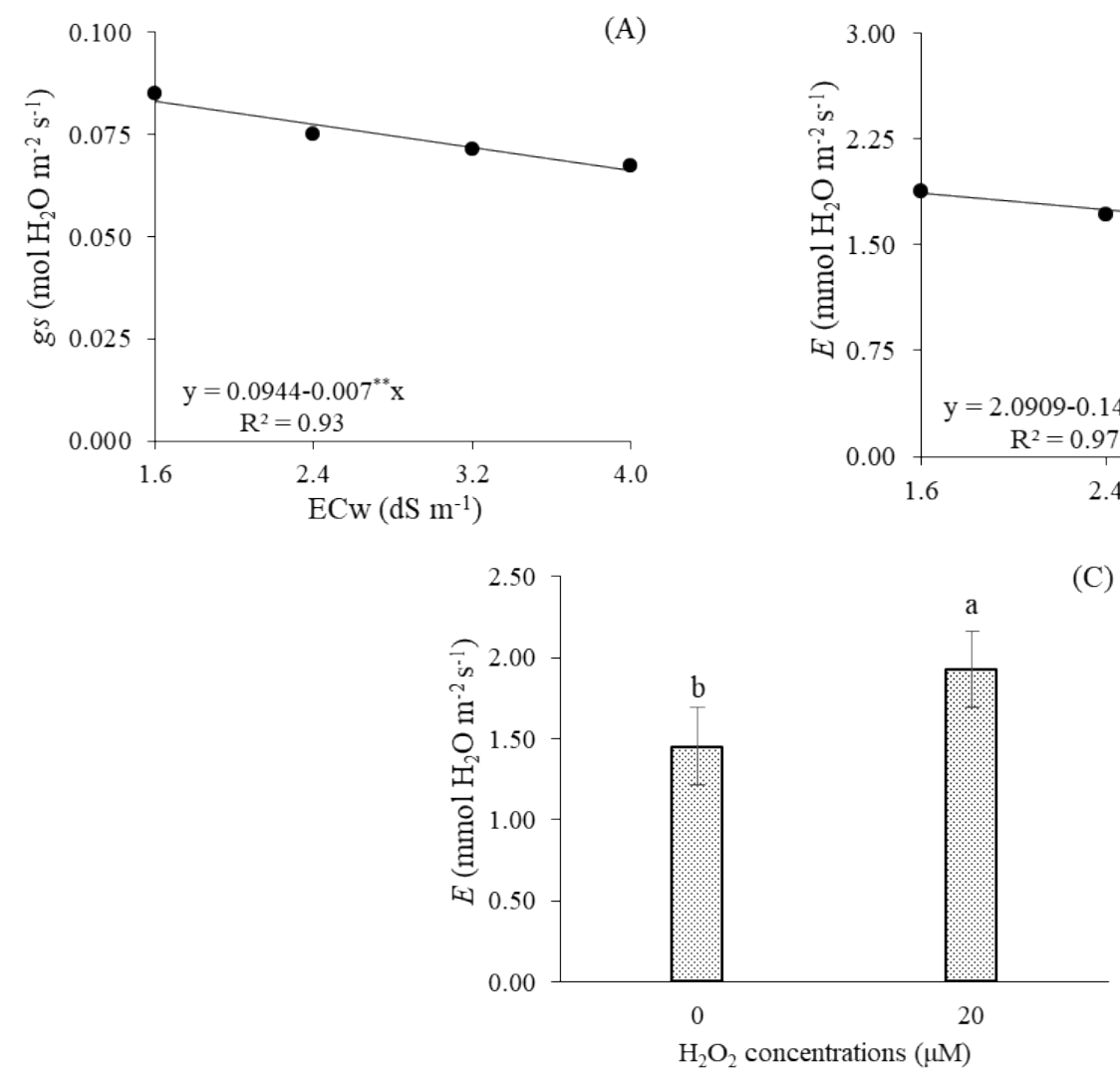

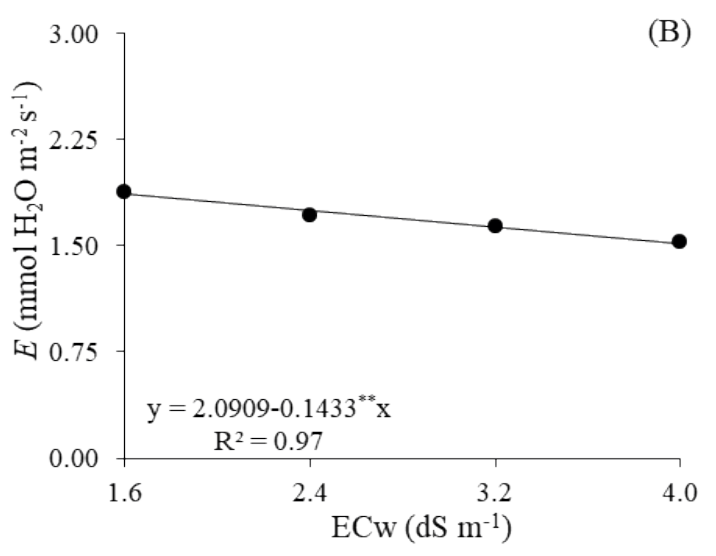

(C)

Figure 1. Stomatal conductance - gs and transpiration - $E$ of soursop 'Morada Nova' as a function of irrigation water salinity - ECw (A and $\mathrm{B}$, respectively) and exogenous application of hydrogen peroxide $-\mathrm{H}_{2} \mathrm{O}_{2}(\mathrm{C}), 150$ days after transplanting. Means followed by the same letter do not differ by Tukey's test $(p<0.05)$.

According to the means comparison test (Figure 1C), it was observed that transpiration of soursop leaves was superior in plants subjected to spraying with $20 \mu \mathrm{M} \mathrm{H}_{2} \mathrm{O}_{2}\left(1.93 \mathrm{mmol} \mathrm{H}_{2} \mathrm{O} \mathrm{m}^{-2} \mathrm{~s}^{-1}\right)$ compared to the control treatment $(0 \mu \mathrm{M})\left(1.45 \mathrm{mmol} \mathrm{H}_{2} \mathrm{O}\right.$ $\left.\mathrm{m}^{-2} \mathrm{~s}^{-1}\right)$. That is, the plants sprayed with $20 \mu \mathrm{M} \mathrm{H}_{2} \mathrm{O}_{2}$ had a $33.10 \%$ increase in the value of $E$ compared to the non-sprayed plants $(0 \mu \mathrm{M})$. Therefore, these results highlight the beneficial effect of exogenous application of small quantities of $\mathrm{H}_{2} \mathrm{O}_{2}$ on the transpiration of soursop leaves, probably caused by the participation of $\mathrm{H}_{2} \mathrm{O}_{2}$ as the main carrier for the modulation of several physiological processes, such as stomatal movement, which, in turn, is directly related to the transpiration rate of the plant since the stomata are surrounded by two guard cells that are the main gateways for plants to profitably consume
$\mathrm{CO}_{2}$ for photosynthesis and to simultaneously regulate the transpiration of water. Furthermore, the exogenous application of $\mathrm{H}_{2} \mathrm{O}_{2}$ can influence plant tolerance to drought, salinity, toxicity, and temperature stress (Nazir, Hussain, \& Fariduddin, 2019).

When analyzing the interaction between irrigation water salinity and concentrations of hydrogen peroxide for the $\mathrm{CO}_{2}$ assimilation rate (Figure 2A), a significant difference was verified for the $\mathrm{H}_{2} \mathrm{O}_{2}$ concentrations when subjecting soursop plants to irrigation with water at a $\mathrm{ECw}$ of 2.4 and $4.0 \mathrm{dS} \mathrm{m}^{-1}$. Plants sprayed with 20 $\mu \mathrm{M} \mathrm{H}_{2} \mathrm{O}_{2}$ and irrigated with $2.4 \mathrm{dS} \mathrm{m}^{-1}$ showed a $35.95 \%$ increase in the value of $A$ compared to the plants that did not receive $\mathrm{H}_{2} \mathrm{O}_{2}$. In turn, the $\mathrm{CO}_{2}$ 
assimilation rate of plants irrigated with $4.0 \mathrm{dS} \mathrm{m}^{-1}$ and subjected to leaf sprays with $20 \mu \mathrm{M} \mathrm{H}_{2} \mathrm{O}_{2}$ was $42.36 \%$, superior to that verified for the plants that did not receive $\mathrm{H}_{2} \mathrm{O}_{2}$. Given these results, it may be inferred that the application of $\mathrm{H}_{2} \mathrm{O}_{2}$ promoted changes in plant metabolism, conferring a greater ability to perform photosynthesis under conditions of higher salt stress. This occurs because hydrogen peroxide is a versatile molecule, which, in adequate concentrations, is involved in the regulation of growth and development in stressful environments, including photosynthetic performance (Khan, Khan, Masood, Per, \& Asgher, 2016). A. A. R. da Silva et al. (2019) verified that passion fruit plants reached the highest $\mathrm{CO}_{2}$ assimilation rate when subjected to $25 \mu \mathrm{M} \mathrm{H}_{2} \mathrm{O}_{2}$ and irrigated with water at $1.4 \mathrm{dS} \mathrm{m}^{-1}$.

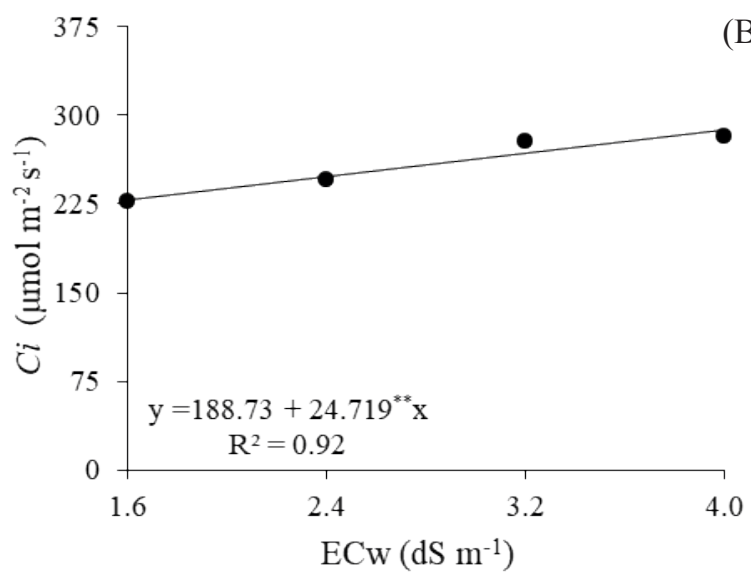

(B)

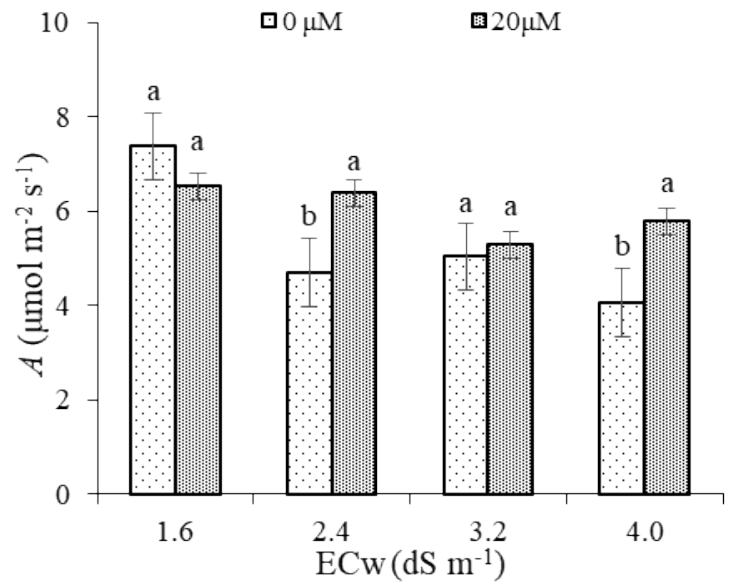

(A)

Figure 2. $\mathrm{CO}_{2}$ assimilation rate - $A$ of soursop 'Morada Nova' as a function of the interaction between irrigation water salinity - ECW and exogenous application of hydrogen peroxide $-\mathrm{H}_{2} \mathrm{O}_{2}(\mathrm{~A})$ and internal concentration of $\mathrm{CO}_{2}-\mathrm{Ci}$ as a function of irrigation water salinity - ECW (B), to 150 days after transplanting. Means followed by the same letter do not differ by Tukey's test $(p<0.05)$.

According to Figure $2 \mathrm{~B}$, it was possible to observe a $13.09 \%$ increment in the internal $\mathrm{CO}_{2}$ concentration $(\mathrm{Ci})$ per unit increase of $\mathrm{ECw}$; that is, the plants irrigated with $4.0 \mathrm{dS} \mathrm{m}^{-1}$ showed a $25.98 \%$ increase in the value of $C i$ compared to plants irrigated with $1.6 \mathrm{dS} \mathrm{m}^{-1}$. Therefore, it can be affirmed that carbon in the substomatal chamber was not used in the production of photoassimilates via the photosynthetic process due to the action of factors of both stomatal and non-stomatal origin. Such a situation agrees with the reduction of stomatal conductance (Figure 1A) and $\mathrm{CO}_{2}$ assimilation rate (Figure 2A) with an increase in salinity. Lima et al. (2018), in a study performed with plants of the West Indian cherry cultivar 'BRS 366 Jaburu' subjected to salt stress (ECw of 0.8 and $3.8 \mathrm{dS} \mathrm{m}^{-1}$ ), observed an increase in $C i$ when the plants were irrigated with water at $4.5 \mathrm{dS} \mathrm{m}^{-1}$ and highlighted that the increase in the internal $\mathrm{CO}_{2}$ concentration was an indicator that there was no restriction in the acquisition of $\mathrm{CO}_{2}$ by the plant. However, upon reaching the mesophilic cells, the process of fixation during carboxylation was compromised, which may be related to degradation of the photosynthetic apparatus in response to the senescence of leaf tissues, resulting from stress caused by excess salt.

According to Table 3, there was a significant interaction $(p<0.05)$ between the salinity levels and hydrogen peroxide concentrations for chlorophyll $a(C h l a)$, chlorophyll $b(C h l b)$, carotenoids (Car) e percentage of cellular damage $(\% \mathrm{D})$ of soursop plants 'Morada Nova'. 
Table 3

Summary of $\mathrm{F}$ test for chlorophyll $\boldsymbol{a}(\mathrm{Chl} \boldsymbol{a})$, chlorophyll $\boldsymbol{b}(\mathrm{Chl} \boldsymbol{b})$, carotenoids (Car) and percentage of cellular damage (\%D) of soursop plants 'Morada Nova' irrigated with saline waters and subjected to exogenous application of hydrogen peroxide, at $\mathbf{1 5 0}$ days after $\mathrm{o}$ transplanting

\begin{tabular}{lcccc}
\hline \multirow{2}{*}{ Source of variation } & \multicolumn{5}{c}{ Teste $\mathrm{F}$} \\
\cline { 2 - 5 } & $\mathrm{Chl} a$ & $\mathrm{Chl} b$ & $\mathrm{Car}$ & $\% \mathrm{D}$ \\
\hline Salinity levels (SL) & $* *$ & $* *$ & $* *$ & $*$ \\
Linear regression & $* *$ & $\mathrm{~ns}$ & $\mathrm{~ns}$ & $\mathrm{~ns}$ \\
Quadratic regression & $* *$ & $* *$ & $* *$ & $* *$ \\
Hydrogen peroxide $\left(\mathrm{H}_{2} \mathrm{O}_{2}\right)$ & $* *$ & $* *$ & $* *$ & $* *$ \\
Interaction $\left(\mathrm{SL} \times \mathrm{H}_{2} \mathrm{O}_{2}\right)$ & $* *$ & $\mathrm{~ns}$ & $\mathrm{~ns}$ & $\mathrm{~ns}$ \\
Blocks & $\mathrm{ns}$ & 16.25 & 17.84 & 9.34 \\
\hline $\mathrm{CV} \%$ & 11.24 & & \\
\hline
\end{tabular}

$\mathrm{ns}, *$ and $* *$ respectively, not significant, significant at $p<0.05$ and $p<0.01$

The content of chlorophyll $a$ in soursop plants was significantly influenced by the interaction between water salinity and $\mathrm{H}_{2} \mathrm{O}_{2}$ concentrations (Figure 3A). It was seen that the content of chlorophyll $a$ in plants irrigated with water at $\mathrm{ECW}$ of $1.6 \mathrm{dS} \mathrm{m}^{-1}$ and sprayed with $20 \mu \mathrm{M} \mathrm{H}_{2} \mathrm{O}_{2}$ was reduced by $304.72 \mathrm{mg} \mathrm{g}^{-1}$ FM compared to plants that did not receive $\mathrm{H}_{2} \mathrm{O}_{2}$. In some cases, exogenous application of hydrogen peroxide may cause damage to plants under a moderate stress situation, since in plants subjected to stress caused by high salinity, the activity of antioxidant enzymes, such as catalase, superoxide dismutase, guaiacol peroxidase, glutathione reductase, and ascorbate reductase, tends to increase. Thus, plants with high antioxidant levels have shown greater tolerance to oxidative stress (Esteves \& Suzuki, 2008). Therefore, the application of hydrogen peroxide has proven to be more efficient in the mitigation of stress in plants irrigated with water at higher $\mathrm{ECw}$ values. In turn, plants subjected to irrigation with $2.4,3.2$, and 4.0
$\mathrm{dS} \mathrm{m}{ }^{-1}$ and sprayed with $20 \mu \mathrm{M} \mathrm{H}_{2} \mathrm{O}_{2}$ presented a content of chlorophyll $a$ superior by $57.21 ; 44.64$ and $71.77 \%$, respectively, compared to plants that did not receive hydrogen peroxide $(0 \mu \mathrm{M})$.

Regarding the content of chlorophyll $b$ (Figure $3 \mathrm{~B}$ ), plants irrigated with $2.4 \mathrm{dS} \mathrm{m}^{-1}$ and sprayed with $20 \mu \mathrm{M} \mathrm{H}_{2} \mathrm{O}_{2}$ presented a higher content of chlorophyll $b$ (394.27 $\mathrm{mg} \mathrm{g}^{-1} \mathrm{FM}$ ) compared to the control treatment $(0 \mu \mathrm{M})$. It was also observed that, at the highest salinity level $\left(4.0 \mathrm{dS} \mathrm{m}^{-1}\right)$, hydrogen peroxide was efficient in mitigating the damage of salinity on the content of chlorophyll $b$ since $\mathrm{H}_{2} \mathrm{O}_{2}$ may have affected the increase of the chlorophyllase enzyme, which is responsible for the degradation of molecules of photosynthetic pigments when the plant is exposed to water salinity (Igiebor, Ikhajiagbe, \& Anoliefo, 2019). Furthermore, the lower pigment degradation induced by hydrogen peroxide may be related to its potential for stimulating the activity of antioxidant enzymes (Ashraf et al., 2015). 

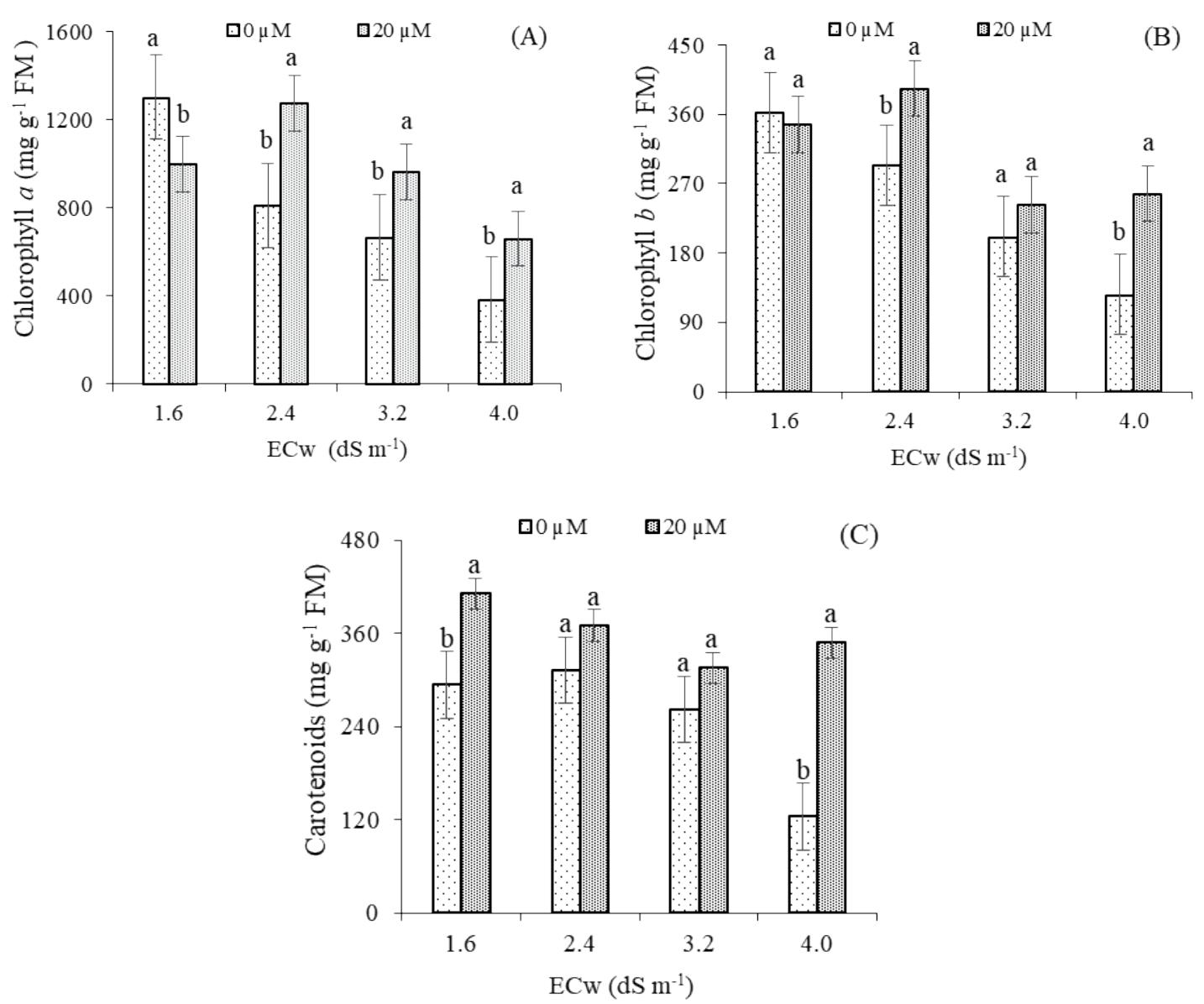

Figure 3. Chlorophyll $a$ (A) and $b$ (B) e carotenoids (C) of soursop 'Morada Nova' as a function of the interaction between irrigation water salinity - $\mathrm{ECw}$ and exogenous application of hydrogen peroxide $-\mathrm{H}_{2} \mathrm{O}_{2}, 150$ days after transplanting. Means followed by the same letter do not differ by Tukey's test $(p<0.05)$.

According to the means comparison test for the content of carotenoids (Figure 3C), a significant difference was observed between the concentrations of hydrogen peroxide in soursop plants irrigated with waters at $\mathrm{ECw}$ levels of 1.6 and $4.0 \mathrm{dS} \mathrm{m}^{-1}$. Plants subjected to leaf spraying with $20 \mu \mathrm{M} \mathrm{H}_{2} \mathrm{O}_{2}$ and irrigated with $1.6 \mathrm{dS} \mathrm{m}^{-1}$ had their content of carotenoids increased by $39.83 \%$ compared to plants that were not sprayed. An expressive difference between $\mathrm{H}_{2} \mathrm{O}_{2}$ concentrations was also verified at an electrical conductivity of $4.0 \mathrm{dS} \mathrm{m}^{-1}$, in which plants sprayed with $20 \mu \mathrm{M} \mathrm{H}_{2} \mathrm{O}_{2}$ evidenced a $179.44 \%$ increase in relation to those that did not receive $\mathrm{H}_{2} \mathrm{O}_{2}$. This shows the efficiency of $\mathrm{H}_{2} \mathrm{O}_{2}$ in mitigating the damage caused by salinity on the content of carotenoids in soursop leaves. The stress signaling function performed by $\mathrm{H}_{2} \mathrm{O}_{2}$ may have possibly unleashed the activation of antioxidant enzymes that persist in plants to mitigate oxidative damage, leading to improvements in the physiological attributes for the growth of plants under stress (Dito \& Gadallah, 2019). Sohag et al. (2020) observed that pre-treatment with hydrogen peroxide notoriously mitigated the reduction of photosynthetic pigments in rice crops under water stress, a type of stress that can be induced by salinity (Soares, Santos, Simões, Pazzin, \& Silva, 2015).

According to the mean comparison test for the percentage of cell damage (Figure 4), a significant difference was observed for hydrogen peroxide 
concentrations in soursop plants irrigated with water at $\mathrm{ECw}$ levels of 2.4, 3.2, and $4.0 \mathrm{dS} \mathrm{m}^{-1}$. When comparing the means between treatments, it was noted that plants sprayed with $20 \mu \mathrm{M} \mathrm{H}_{2} \mathrm{O}_{2}$ and irrigated with $2.4 \mathrm{dS} \mathrm{m}^{-1}$ showed a $23.74 \%$ increase in cell damage compared to the nonsprayed plants. In turn, plants irrigated with 3.2 and $4.0 \mathrm{dS} \mathrm{m}^{-1}$ presented lower damage rates in leaf tissues (23.86 and $25.96 \%$, respectively), although the non-sprayed plants evidenced greater damage to the integrity of the cell membrane (33.83 and $33.46 \%$, respectively). Thus, the action of hydrogen peroxide in avoiding or reducing the disorganization of the cell membrane caused by salinity, at more intense levels, becomes notorious. Nunes, Pinheiro, Cabral, Silva and Dutra (2019) discovered that irrigation with saline water leads to an increment in the damage to the cell membrane in bean plants and at the highest tested salinity level $\left(7.5 \mathrm{dS} \mathrm{m}^{-1}\right)$, the release of electrolytes in these tissues increased about 1.2 times compared to the control treatment $\left(0.0 \mathrm{dS} \mathrm{m}^{-1}\right)$.

Stem diameters of the rootstock $\left(\mathrm{SD}_{\text {rootstock }}\right)$ at the grafting point $\left(\mathrm{SD}_{\text {grafting point }}\right)$ and of the scion $\left(\mathrm{SD}_{\text {scion }}\right)$ responded significantly $(\mathrm{p}<0.05)$ to the interaction between irrigation water salinity and $\mathrm{H}_{2} \mathrm{O}_{2}$ concentration at 150 DAT (Table 4).

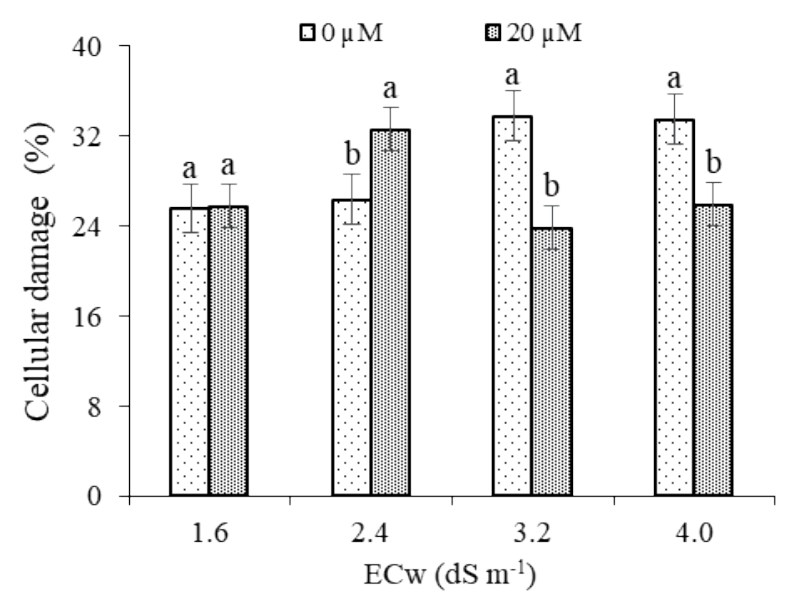

Figure 4. Percentage of cellular damage $(\% \mathrm{D})$ of soursop 'Morada Nova' as a function of the interaction between irrigation water salinity - ECw and exogenous application of hydrogen peroxide $-\mathrm{H}_{2} \mathrm{O}_{2}, 150$ days after transplanting. Means followed by the same letter do not differ by Tukey's test $(p<0.05)$. 


\section{Table 4}

Summary of $\mathrm{F}$ test for rootstock diameter ( $\left.\mathrm{SD}_{\text {rootstock }}\right)$, grafting point diameter $\left(\mathrm{SD}_{\text {grafting point }}\right)$, and scion diameter $\left(\mathrm{SD}_{\text {scion }}\right)$ of soursop plants 'Morada Nova' irrigated with saline waters and subjected to exogenous application of hydrogen peroxide, at 150 days after $o$ transplanting

\begin{tabular}{lccc}
\hline \multirow{2}{*}{ Source of variation } & \multicolumn{2}{c}{$\mathrm{F}$ Test } \\
\cline { 2 - 4 } & $\mathrm{SD}_{\text {rootstock }}$ & $\mathrm{SD}_{\text {grafting point }}$ & $\mathrm{SD}_{\text {scion }}$ \\
\hline Salinity levels $(\mathrm{SL})$ & $* *$ & $* *$ & $* *$ \\
$\quad$ Linear regression & $\mathrm{ns}$ & $* *$ & $* *$ \\
Quadratic regression & $\mathrm{ns}$ & $* *$ & $* *$ \\
Hydrogen peroxide $\left(\mathrm{H}_{2} \mathrm{O}_{2}\right)$ & $* *$ & $* *$ & $* *$ \\
Interaction $\left(\mathrm{SL} \times \mathrm{H}_{2} \mathrm{O}_{2}\right)$ & $* *$ & $* *$ & $* *$ \\
Blocks & $\mathrm{ns}$ & $\mathrm{ns}$ & $\mathrm{ns}$ \\
\hline $\mathrm{CV} \%$ & 5.07 & 5.18 & 6.39 \\
\hline
\end{tabular}

$\mathrm{ns}, *$, ** Respectively, not significant, significant at $p<0.05$ and $p<0.01$.

According to Figure 5A, there was a significant difference between plants that were sprayed with 20 $\mu \mathrm{M} \mathrm{H}_{2} \mathrm{O}_{2}$ and those that were not, at the different EC levels of the irrigation water. It was also highlighted that, at salinity levels of 1.6 and $4.0 \mathrm{dS} \mathrm{m}^{-1}$, plants sprayed with $20 \mu \mathrm{M} \mathrm{H}_{2} \mathrm{O}_{2}$ had respective increase rates of 11.76 and $12.50 \%$ compared to those that were not sprayed. However, at salinity levels of 2.4 and $3.0 \mathrm{dS} \mathrm{m}^{-1}$, non-sprayed plants presented larger rootstock diameters compared to the sprayed plants. Plants subjected to salt stress usually had reduced growth due to the metabolic damage caused by osmotic and ionic imbalance. Therefore, to express their survival potential in a saline medium, some plants try to osmotically adjust to it (Lima et al., 2019). In view of that, $\mathrm{H}_{2} \mathrm{O}_{2}$ can induce tolerance, promoting the accumulation of soluble proteins, soluble carbohydrates, and $\mathrm{NO}_{3}^{-}$, as well as reducing the content of $\mathrm{Na}^{+}$and $\mathrm{Cl}^{-}$in plants (Gondim, Gomes, Marques, \& Prisco, 2011). A. A. R. da Silva et al. (2019), evaluating the physiology and growth of passion fruit seedlings under salt stress and concentrations of hydrogen peroxide, verified that a $25 \mu \mathrm{M}$ concentration of hydrogen peroxide mitigates the negative effects of a $1.4 \mathrm{dS} \mathrm{m}^{-1}$ water salinity level on these aspects. 

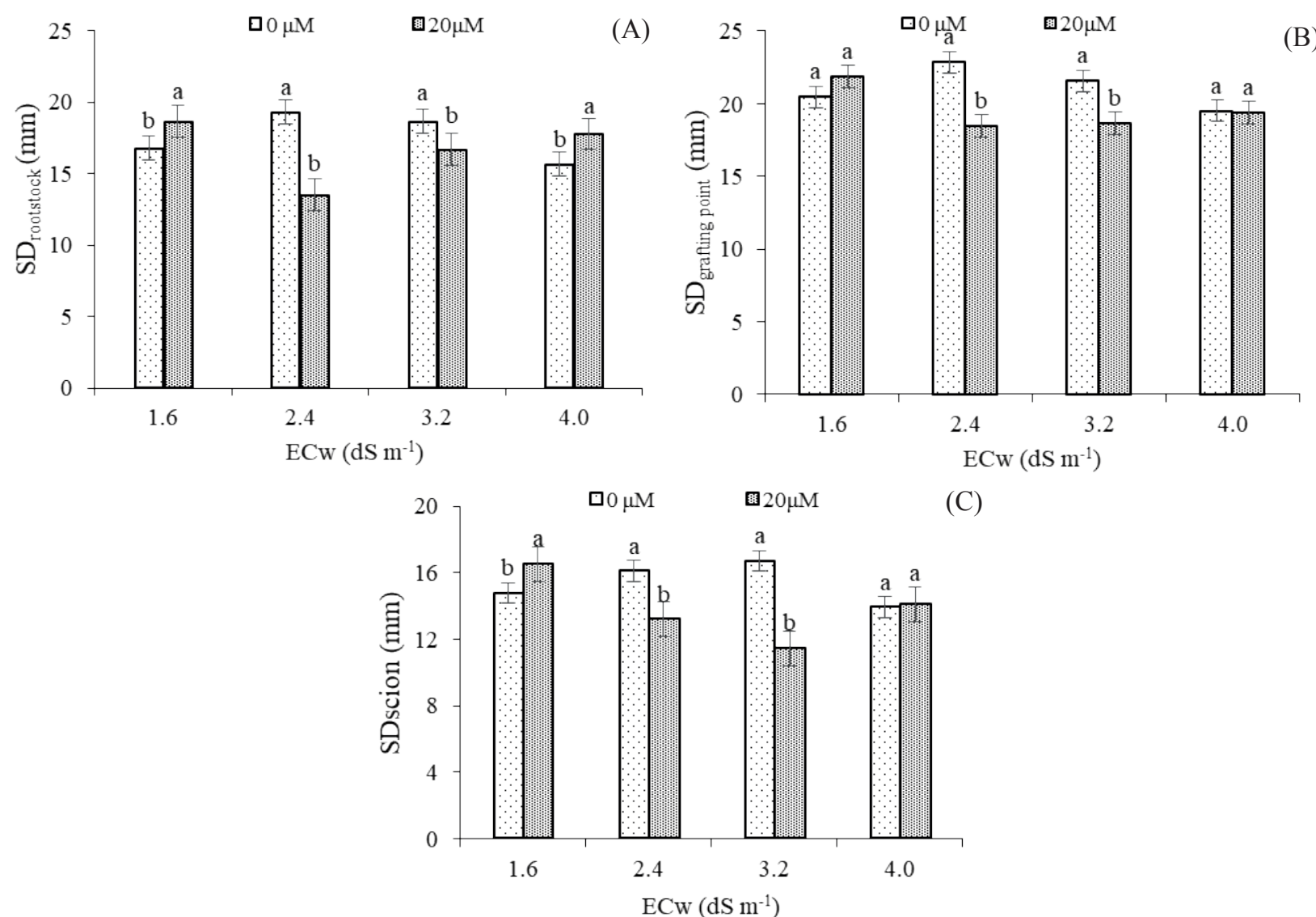

Figure 5. Rootstock diameter $-\mathrm{SD}_{\text {rootstock }}(\mathrm{A})$, grafting point diameter - SDgrafting point (B) and scion diameter - SDscion (C) of soursop as a function of the interaction between irrigation water salinity - ECw and exogenous application of hydrogen peroxide $-\mathrm{H}_{2} \mathrm{O}_{2}, 150$ days after transplanting. Means followed by the same letter do not differ by Tukey's test $(p<0.05)$.

Regarding the stem diameter at the grafting point (Figure 5B), the mean comparison test revealed that there was a significant difference between $\mathrm{H}_{2} \mathrm{O}_{2}$ concentrations at salinity levels of 2.4 and $3.2 \mathrm{dS}$ $\mathrm{m}^{-1}$; in turn, plants that were not sprayed with $\mathrm{H}_{2} \mathrm{O}_{2}$ $(0 \mu \mathrm{M})$ exhibited a larger grafting point diameter compared to plants sprayed with $20 \mu \mathrm{M} \mathrm{H}_{2} \mathrm{O}_{2}$, with values of (27.77 and $15.78 \%$ ), respectively. As for the plants subjected to irrigation with 1.6 and $4.0 \mathrm{dS}$ $\mathrm{m}^{-1}$, there was no significant difference between the concentrations of $\mathrm{H}_{2} \mathrm{O}_{2}$.

The stem diameter of the rootstock (Figure 5C) in plants irrigated with $4.0 \mathrm{dS} \mathrm{m}^{-1}$ and sprayed with $20 \mu \mathrm{M} \mathrm{H}_{2} \mathrm{O}_{2}$ was not significantly different from non-sprayed plants. As for the $\mathrm{ECw}$ of $1.6 \mathrm{dS} \mathrm{m}^{-1}$, plants sprayed with $20 \mu \mathrm{M} \mathrm{H}_{2} \mathrm{O}_{2}$ presented $13.33 \%$ increase compared to those that were not sprayed. The opposite effect occurred in plants subjected to irrigation with 2.4 and $3.2 \mathrm{dS} \mathrm{m}^{-1}$, which showed considerable increase rates of 23.07 and $54.54 \%$, respectively. Under salt stress conditions, a reduction in osmotic potential was the main effect that plants manifested. Stomatal closure was a consequence of this effect (Figure 1A), consequently reducing water and nutrient absorption by plants, which resulted in lower growth (Souza, Mendonça, Sá, Silva, \& Dourado, 2020). However, when applied in adequate quantities and depending on the level of stress to which the plant was subjected, hydrogen peroxide can reduce the cell osmotic potential and favor the absorption of water and nutrients, based on the production of organic solutes (Ge et al., 2015). 


\section{Conclusions}

The increase in salinity of irrigation water, beginning from $1.6 \mathrm{dS} \mathrm{m}^{-1}$, resulted in alterations in stomatal conductance, transpiration, and internal $\mathrm{CO}_{2}$ concentration of soursop plants at 150 days after transplantation.

A $20 \mu \mathrm{M}$ concentration of $\mathrm{H}_{2} \mathrm{O}_{2}$ mitigated the effects of salinity on the transpiration and $\mathrm{CO}_{2}$ assimilation rate, besides increasing the biosynthesis of photosynthetic pigments and reducing the percentage of cell damage in soursop plants.

Exogenous application of $20 \mu \mathrm{M} \mathrm{H}_{2} \mathrm{O}_{2}$ reduced the deleterious effect of salinity on the stem diameter of both rootstock and scion in soursop plants irrigated with water of an ECw of $1.6 \mathrm{dS} \mathrm{m}^{-1}$.

Exogenous application of $20 \mu \mathrm{M} \mathrm{H}_{2} \mathrm{O}_{2}$ was not efficient in mitigating the damage caused by salinity on the stem diameter at the grafting point of soursop plants.

\section{References}

Arnon, H. P.-A., Emam, Y., Rousta, M. J., \& Ashraf, M. (2017). Salicylic acid induced salinity tolerance through manipulation of ion distribution rather than ion accumulation. Journal of Plant Growth Regulation, 36(1), 227-239. doi: 10.1007/s00344016-9633-y

Ashraf, M. A., Rasheed, R., Hussain, I., Iqbal, M., Haider, M. Z., Parveen, S., \& Sajid, M. A. (2015). Hydrogen peroxide modulates antioxidant system and nutrient relation in maize (Zea mays L.) under water-deficit conditions. Archives of Agronomy and Soil Science, 61(4), 507-523. doi: 10.1080/036503 40.2014.938644

Byuna, E.-B., Songab, H.-Y., \& Kima, W. S. (2020). Polysaccharides from Annona muricata leaves protect normal human epidermal keratinocytes and mice skin from radiation-induced injuries. Radiation Physics and Chemistry, 170(1), 108672. doi: 10.1016/j.radphyschem.2019.108672

Carvalho, F. E. L., Lobo, A. K. M., Bonifacio, A., Martins, M. O., Lima, M. C., Neto, \& Silveira, J. A. G. (2011). Aclimatação ao estresse salino em plantas de arroz induzida pelo pré-tratamento com
$\mathrm{H}_{2} \mathrm{O}_{2}$. Revista Brasileira de Engenharia Agrícola e Ambiental, 15(4), 416-423. doi: 10.1590/S141543662011000400014

Černý, M., Habánová, H., Berka, M., Luklová, M., \& Brzobohatý, B. (2018). Hydrogen peroxide: its role in plant biology and crosstalk with signalling networks. Intanation Journal of Molecular Science, 19(9), 2812. doi: 10.3390/ijms 19092812

Cova, A. M. W., Azevedo, A. D., Neto, Silva, P C. C., Menezes, R. V., Ribas, R. F., \& Gheyi, H. R. (2020). Physiological and biochemical responses and fruit production of noni (Morinda citrifolia L.) plants irrigated with brackish water. Scientia Horticulturae, 260(1), 108852. doi: 10.1016/j.scienta.2019.108 852

Dito, S., \& Gadallah, M. (2019). Hydrogen peroxide supplementation relieves the deleterious effects of cadmium on photosynthetic pigments and oxidative stress and improves the growth, yield and quality of pods in pea plants (Pisum sativum L.). Acta Physiologiae Plantarum, 41(113), 2-12. doi: 10.1007/s 11738-019-2901-2

Esteves, B. dos S., \& Suzuki, M. S. (2008). Efeito da salinidade sobre as plantas. Oecologia Brasiliensis, 12(4), 6.

Ferreira, D. F. (2019). SISVAR: a computer analysis system to fixed effects split plot type designs. Revista Brasileira de Biometria, 37(1), 529-535. doi: 10.1590/S1413-70542014000200001

Ge, X. M., Cai, H. L., Lei, X., Zhou, X., Yue, M., \& He, J. M. (2015). Heterotrimeric G protein mediates ethylene-induced stomatal closure via hydrogen peroxide synthesis in Arabidopsis. The Plant Journal, 82(1), 138-150. doi. 10.1111/tpj.12799

Gondim, F. A., Gomes, E., Fº, Marques, E. C., \& Prisco, J. T. (2011). Efeitos do $\mathrm{H}_{2} \mathrm{O}_{2}$ no crescimento e acúmulo de solutos em plantas de milho sob estresse salino. Revista Ciência Agronômica, 42(2), 373-38. doi: 10.1590/S1806-66902011000200016

Gondim, F. A., Miranda, R. de S., Gomes, E., Fº, \& Prisco, J. T. (2013). A tolerância aprimorada ao sal em plantas de milho induzida por pulverização de folhas de $\mathrm{H}_{2} \mathrm{O}_{2}$ está associada a uma troca de gases melhorada do que ao sistema antioxidante não enzimático. Theoretical and Experimental Plant Physiology, 25(4), 251-260. doi: 10.1590/S219700252013000400003

Hasan, Z., Sabet, M. S., Malakouti, M. J., MokhtassiBidgoli, A., \& Homaee, M. (2020). Zinc and potassium fertilizer recommendation for cotton seedlings under salinity stress based on gas exchange 
and chlorophyll fluorescence responses South African Journal of Botany, 130(1), 155-164. doi: 10.1016/j. sajb.2019.11.032

Igiebor, F. A., Ikhajiagbe, B., \& Anoliefo, G. O (2019). Growth and development of salinity-exposed rice (Oryza sativa) rhizo-inoculated with Bacillus subtilis under different $\mathrm{pH}$ levels. Studia Universitatis Babes-Bolyai, Biologia, 64(1), 41-53. doi: 10.24193/ subbbiol.2019.2.04

Khan, M. I., Khan, N. A., Masood, A., Per, T. S., \& Asgher, M. (2016). Hydrogen peroxide alleviates nickel-inhibited photosynthetic responses through increase in use efficiency of nitrogen and sulfur, and glutathione production in mustard. Frontiers Plant Science, 3(1), 44. doi: 10.3389/fpls.2016.00044

Lima, G. S. de, Dias, A. S., Souza, L. de P., Sá, F. V. da S., Gheyi, H. R., \& Soares, L. A. dos A. (2018). Effects of saline water and potassium fertilization on photosynthetic pigments, growth and production of West Indian cherry. Revista Ambiente Água, 13(3), e2164. doi: 10.4136/ambi-agua.2164

Lima, G. S. de, Dias, A. S., Soares, L. A. dos A., Gheyi, H. R., Nobre, R. G., \& Silva, A. A. R. da. (2019). Eficiência fotoquímica, partição de fotoassimilados e produção do algodoeiro sob estresse salino e adubação nitrogenada. Revista de Ciências Agrárias, 42(1), 211-220. doi: 10.19084/RCA18123

Liu, L., Huang, L., Lin, X., \& Sun, C. (2020). Hydrogen peroxide alleviates salinity-induced damage through enhancing proline accumulation in wheat seedlings. Plant Cell Reports, 12(1), 1-9. doi: 10.1007/s002 99020-02513-3

Medeiros, J. F. de. (1992). Qualidade de água de irrigação e evolução da salinidade nas propriedades assistidas pelo GAT nos Estados de RN, PB e CE. Dissertação de mestrado, Universidade Federal da Paraíba, Campina Grande, Brasil.

Minhas, P. S., Ramos, T. B., Ben-Gal, A., \& Pereira, L. S. (2020). Coping with salinity in irrigated agriculture: Crop evapotranspiration and water management issues. Agricultural Water Management, 227(1), 105832. doi: 10.1016/j.agwat.2019.105832

Nahida, A. M. D., Ahsanul, H. O. Q., Sharmin, J., Md. Mainul, I., Firoz, A., \& Shahid-ud-daula, A. F. M., \& Hasanuzzaman, M. D. (2020). Methanol soluble fraction of fruits of Annona muricata possesses significant antidiarrheal activities. Heliyon, 6(1), e03112. doi: 10.1016/j.heliyon.2019.e03112

Nazir, F., Fariduddin, Q., \& Khan, T. A. (2020). Hydrogen peroxide as a signalling molecule in plants and its crosstalk with other plant growth regulators under heavy metal stress. Chemosphere, 1(1), 126486. doi: 10.1016/j.chemosphere.2020.126486

Nazir, F., Hussain, A., \& Fariduddin, Q. (2019). Interactive role of epibrassinolide and hydrogen peroxide in regulating stomatal physiology, root morphology, photosynthetic and growth traits in Solanum lycopersicum L. under nickel stress. Environmental and Experimental Botany, 162(1), 479-495. doi: 10. 1016/j.envexpbot.2019.03.021

Novais, R. F., Neves, J. C. L., \& Barros, N. F. (1991). Ensaio em ambiente controlado. In A. J. Oliveira, W. E. Garrido, J. D. Araújo, \& S. Lourenço (Eds.), Métodos de pesquisa em fertilidade do solo (pp. 189253). Brasília: EMBRAPA SEA.

Nunes, L. R. de L., Pinheiro, P. R., Cabral, F. A. S., Silva, J. B. da, \& Dutra, A. S. (2019). Ascorbic acid of cowpea seeds under saline stress. Journal of Seed Science, 41(4), 441-451. doi: 10.1590/2317-1545v41 n4222276

Pailles, Y., Awlia, M., Julkowska, M., Passone, L., Zemmouri, K., Negrão, S., \& Tester, M. (2020). Diverse traits contribute to salinity tolerance of wild tomato seedlings from the Galapagos Islands. Plant Physiology, 182(1), 534-546. doi: 10.1104/ pp. 19.00700

Richards, L. A. (1954). Diagnosis and improvement of saline and alkali soils. Washington: U. S. Department of Agriculture. Agriculture Handbook, 60.

Santana, E. B., Jr., Coelho, E. F., Gonçalves, K. S., \& Cruz, J. L. (2019). Physiological and vegetative behavior of banana cultivars under irrigation water salinity. Revista Brasileira de Engenharia Agrícola e Ambiental, 24(2), 82-88. doi: 10.1590/1807-1929/ agriambi.v24n2p $82-88$

Silva, A. A. R. da, Lima, G. S. de, Azevedo, C. A. V. de, Gheyi, H. R., Souza, L. de P., \& Veloso, L. L. de S. A. (2019). Gas exchanges and growth of passion fruit seedlings under salt stress and hydrogen peroxide. Pesquisa Agropecuária Tropical, 49(1), e55671. doi: 10.1590/1983-40632019v4955671

Silva, F. D. F., Rocha, M. D. S., Brito, J. F. de, Neto, Sofiatti, V., \& Beltrao, N. D. M. (2011). Extravasamento de eletrólitos em algodão herbáceo submetido a alta temperatura e elevado nível de $\mathrm{CO}_{2}$. In Anais do Congresso Brasileiro do Algodão, Cotton Expor, Campina Grande, PB, Brasil, 8.

Simões, W. L., Coelho, D. S., Mesquita, A. C., Calgaro, M., \& Silva, J. S. da. (2020). Physiological and biochemical responses of sugarcane varieties to salt stress. Revista Caatinga, 32(1), 1069-1076. doi: 10. 1590/1983-21252019v32n423rc 
Soares, M. M., Santos, H. C. dos, Jr., Simões, M. G., Pazzin, D., \& Silva, L. J. da. (2015). Estresse hídrico e salino em sementes de soja classificadas em diferentes tamanhos. Pesquisa Agropecuária Tropical, 45(4), 370-378. doi: 10.1590/1983$40632015 \mathrm{v} 4535357$

Sohag, A. A. M., Tahjib-Ul-Arif, M., Brestič, M., Afrin, S., Sakil, M. A., Hossain, M. T., \& Hossain, M. A. (2020). Exogenous salicylic acid and hydrogen peroxide attenuates drought stress in rice. Plant Soil and Environment, 66(1), 7-13. doi: 10.17221/472/2019-PSE

Souza, T. M. A. de, Mendonça, V., Sá, F. V. da S., Silva, M. J. da, \& Dourado, C. S. T. (2020). Silicato de cálcio como atenuador de estresse de sal em mudas de fruta de paixão amarela cv. BRS ga1. Revista Caatinga, 33(2), 509-517. doi: 10.1590/1983-21252020v33n223rc
Teixeira, P. C., Donagemma, G. K., Fontana, A., \& Teixeira, W. G. (2017). Manual de métodos de análise de solo. Rio de Janeiro: EMBRAPA.

Veloso, L. L. S. A., Nobre, R. G., Barbosa, J. L., Lima, G. S., Melo, E. N., Gheyi, H. R., \& Goncalves, E. B., Souza, C. M. A. (2018). Quality of soursop (Annona muricata L.) seedlings under different water salinity levels and nitrogen fertilization. Australian Journal of Crop Science, 12(2), 306-310. doi: 10. 21475/ ajcs.18.12.02.pne892

Yuping, L., Hongbin, L., Yuanyuan, L., \& Suiqi, Z. (2017). Improving water-use efficiency by decreasing stomatal conductance and transpiration rate to maintain higher ear photosynthetic rate in drought-resistant wheat. The Crop Journal, 5(1), 231-239. doi: 10.1016/j.cj.2017.01.001 